\title{
Analisis SWOT sebagai Dasar Perumusan Strategi Pemasaran Berdaya Saing (Studi Kasus pada Dasom Beauty \& Me Nail Surabaya)
}

\author{
* Erniwati Halawa \\ Program Studi Manajemen Fakultas Ekonomi dan Bisnis \\ Universitas Bhayangkara Surabaya, Indonesia
}

\begin{abstract}
Abstrak
DOI: $10.46821 /$ benchmark.v1i2.143

Dasom Beauty \& Me Nail Surabaya berada pada kuadran 1, posisi ini menandakan perusahaan yang kuat dan berpeluang maka strategi yang harus diterapkan adalah SO yaitu : Meningkatkan kualitas pelayanan kepada pelanggan dan membangun hubungan dekat sehingga pelanggan tetap kembali karena pelayanan adalah hal dasar untuk memasarkan suatu produk, Meningkatkan produk yang beragam sehingga dapat menjadi nilai tambah terhadap pelanggan, Mempertahankan sistem administrasi sehingga proses dalam setiap treatment lebih efesien dan efektif. Adapun strategi bersaing menggunakan Matrik Internal-Eksternal yaitu : Memberikan potongan atau diskon di waktu tertentu sehingga dapat bersaing dengan perusahaan yang sejenis, meningkatkan pengembangan inovasi model kecantikan serta cara treatment baru, meningkatkan pengetahuan dan penguasaan terhadap karyawan, karna karyawan adalah ujung tombak jalannya perusahaan, meningkatkan produk yang beragam sehingga dapat menjadi nilai tambah terhadap pelanggan.
\end{abstract}

Kata kunci : Analisis SWOT, Pemasaran, Strategi Perusahaan

Swot Analysis as a Basis for Formulation of Competitive Marketing Strategies

(Case Study on Dasom Beauty \& Me Nail Surabaya)

\begin{abstract}
Dasom Beauty \& Me Nail Surabaya is in quadrant 1, this position indicates a strong and potential company, the strategy that must be applied is SO, that is: Improving service quality to customers and building close relationships so that customers keep returning because service is the basic thing to market a product, Improving diverse products so that it can be added value to customers, Maintaining an administrative system so that the process of each treatment is more efficient and effective. The competitive strategy uses the Internal-External Matrix, that is : Giving discounts at a certain time so that it can compete with similar companies, improve the development of beauty model innovations and new treatments, increase knowledge and mastery of employees, because employees are the spearhead of the company's path, increasing diverse products so they can add value to customers.
\end{abstract}

Keywords: SWOT Analysis, Marketing, Company Strategy

\section{PENDAHULUAN}

Seiring dengan berkembangnya era globalisasi yang semakin cepat dalam pendidikan serta perekonomian yang lebih berkembang, perubahan yang inovatif dalam berbagai aspek perdagangan yang semakin global, diantaranya dalam bidang industri, sosial, perdagangan, ekonomi, budaya, dan lain-lain. Perubahan-perubahan tersebut muncul 
akibat dari kebutuhan manusia yang semakin meningkat, sehingga dapat dikatakan bahwa dengan kemajuan tersebut kebutuhan manusia berkembang dengan cepat. Hal ini memaksa perusahaan untuk lebih memperhatikan lingkungan yang dapat mempengaruhi kelangsungan usahanya, dan dapat mengetahui strategi pemasaran seperti apa dan bagaimana yang harus diterapkan dalam perusahaan. Perkembangan dunia kecantikan saat ini sudah sedemikian pesat sejalan dengan perkembangan dunia tata rias. Keterlibatan teknologi digital tak dapat dipungkiri menjadi salah satu bagian dari perubahan tren maupun perilaku masyarakat terhadap tren itu sendiri.

Dasom Beauty \& Me Nail adalah salah satu klinik kecantikan yang berada di Jl. Kalisari Utara I No.107, Kec. Mulyorejo, Kota Surabaya, berdiri sejak 19 januari 2009 dan mulai mengeluarkan beberapa rangkaian produk dengan inovasi dan kreasi baru. Klinik tersebut saat ini menjadi salah satu alternatif bagi masyarakat khususnya kaum wanita untuk melakukan perawatan wajah, dan produk yang disediakanpun termasuk lengkap dengan harga yang terjangkau. Berbagai produk perawatan wajah dan tubuh disediakan oleh klinik kecantikan Dasom Beauty \& Me Nail guna memenuhi kebutuhan konsumennya. Selama ini Dasom Beauty \& Me Nail belum menerapkan analisis SWOT untuk meningkatkan usahanya, namun perusahaan ini menyadari kuatnya ancaman dan peluang yang dapat mempengaruhi perkembangan industri tersebut.

Berkaitan dengan hal tersebut maka peneliti tertarik untuk melakukan penelitian tentang Analisis SWOT Sebagai Dasar Perumusan Strategi Pemasaran Berdaya Saing ( Studi kasus pada Dasom Beauty \& Me Nail Surabaya).

\section{TINJAUAN PUSTAKA}

\section{Manajemen Pemasaran}

Menurut Suparyanto dan Rosad (2015:1) manajemen pemasaran adalah proses menganalisis, merencanakan, mengatur, dan mengelola program-program yang mencakup pengkonsepan, penetapan harga, promosi dan distribusi dari produk, jasa dan gagasan yang dirancang untuk menciptakan dan memelihara pertukaran yang menguntungkan dengan pasar sasaran untuk mencapai tujuan perusahaan.

Menurut AMA (American Marketing Association) dalam Kotler dan Keller (2016: 9) pemasaran adalah aktivitas, serangkaian institusi, dan proses untuk menciptakan, berkomunikasi, memberikan, dan bertukar penawaran yang memiliki nilai bagi pelanggan, klien, mitra, dan masyarakat luas.

\section{Bauran Pemasaran}

Menurut Kotler dan Amstrong (2016 :51), bauran pemasaran (Marketing Mix) adalah perangkat alat pemasaran taktis yang dapat dikendalikan yaitu : produk, harga, distribusi, dan promosi yang dipadukan oleh perusahaan untuk mencapai tujuan yang diinginkan dalam pasar sasaran.

\section{Analisis SWOT}

Menurut Rangkuti (2019:19), analisis SWOT adalah identifikasi berbagai faktor secara sistematis untuk merumuskan strategi perusahaan yang digunakan untuk mengevaluasi (Strenght, Weakness, Opportunities, dan Threats) dalam suatu proyek atau usaha. 


\section{METODE PENELITIAN}

\section{Jenis Data}

\section{a. Data Primer}

Yaitu data yang dibuat oleh peneliti untuk maksud khusus menyelesaikan permasalahan yang sedang ditanganinya. Data dikumpulkan sendiri oleh peneliti langsung dari sumber pertama atau tempat objek penelitian dilakukan.

b. Data Sekunder

Merupakan data yang didapatkan dari dokumen-dokumen yang dimiliki oleh perusahaan atau yang telah disimpan oleh perusahaan serta data yang telah ditulis dan digunakan oleh peneliti lain. Data sekunder yang diperlukan atau digunakan dalam penelitian ini.

\section{Sumber Data}

a. Hasil wawancara dan interview kepada pimpinan dan karyawan Dasom Beauty \& Me Nail Surabaya.

b. Buku-buku referensi pendukung untuk melengkapi penelitian Analisis SWOT untuk merencanakan strategi perusahaan.

c. Jurnal skripsi terdahulu yang dapat menjadi bahan study pembanding dalam melakukan penelitian.

d. Observasi sebagai teknik pengumpulan data yang spesifik.

\section{Lokasi dan Waktu Penelitian}

Lokasi dari objek penelitian di Dasom Beanty \& Me Nail Surabaya. Salah satu perusahaan yang bergerak dibidang kecantikan yang berada di jl. Kalisari Wonorejo Surabaya Jawa Timur. Penelitian yang diambil mulai 30 Desember 2019 sampai 30 Juni 2020.

\section{HASIL ANALISIS DAN PEMBAHASAN}

\section{Data Hasil Kuesioner}

Data hasil kuesioner ini merupakan hasil dari pengolahan kuesioner yang telah diisi oleh responden, yang dilakukan di Dasom Beauty and Me Nail Surabaya.

\section{Tabel 1}

Kuesioner Internal Faktor Analisis Strategi untuk Mengetahui Kekuatan (Strengths)

\begin{tabular}{lccc}
\hline Faktor Strategi & Bobot & Rating & SKOR (Bobot x Rating) \\
\hline $\begin{array}{l}\text { 1. Memberikan produk yang berkualitas kepada } \\
\text { konsumen }\end{array}$ & 0.143 & 3.4 & 0.49 \\
2. Memberikan pelayanan yang baik kepada & 0.146 & 3.2 & 0.47 \\
$\begin{array}{l}\text { konsumen } \\
\text { 3. Harga yang diberikan terjangkau }\end{array}$ & 0.143 & 3.5 & 0.50 \\
4. Adanya pelatihan bagi karyawan & 0.143 & 3.4 & 0.49 \\
5. Produknya Beragam & 0.139 & 3.3 & 0.46 \\
6. Memiliki sistem administrasi sehingga lebih & 0.143 & 3.7 & 0.53 \\
efektif dan efisien & & & 0.44 \\
7. Hubungan antara atasan dan bawahan baik & 0.143 & 3.1 & 3.37 \\
TOTAL & 1 & & \\
\hline
\end{tabular}

Sumber: Data Diolah, 2020 


\section{Tabel 2}

Kuesioner Internal Faktor Analisis Strategi untuk Mengetahui Kelemahan

(Weaknesses)

\begin{tabular}{lccc}
\hline Faktor Strategi & Bobot & Rating & SKOR (Bobot x Rating) \\
\hline $\begin{array}{l}\text { 1. Lokasi kurang strategis } \\
\text { 2. Media Promosi kurang aktif }\end{array}$ & 0.175 & -2.2 & -0.39 \\
$\begin{array}{l}\text { 3. Kurangnya tenaga kerja yang ahli di } \\
\text { beberapa bidang tertentu }\end{array}$ & 0.154 & -2.9 & -0.45 \\
$\begin{array}{l}\text { 4. Minimnya Pengetahuan } \\
\text { keterampilan karyawan }\end{array}$ & 0.167 & -3.2 & -0.52 \\
$\begin{array}{l}\text { 5. Produk bestseller sering kehabisan } \\
\text { 6. Kedisiplinan karyawan }\end{array}$ & 0.171 & -2.5 & -0.28 \\
TOTAL & 0.171 & -3.2 & -0.43 \\
\hline
\end{tabular}

Sumber: Data Diolah, 2020

Tabel 3

Kuesioner Internal Faktor Analisis Strategi untuk Mengetahui Peluang (Opportunities)

\begin{tabular}{lccc}
\hline Faktor Strategi & Bobot & Rating & SKOR (Bobot x Rating) \\
\hline $\begin{array}{l}\text { 1. Kebutuhan akan kecantikan terus } \\
\text { meningkat setiap hari }\end{array}$ & 0.176 & 2.9 & 0.51 \\
$\begin{array}{l}\text { 2. Mengembangkan inovasi kecantikan } \\
\text { dan treatment kecantikan }\end{array}$ & 0.155 & 3.1 & 0.48 \\
$\begin{array}{l}\text { 3. Penambahan jumlah penduduk yang } \\
\quad 0.172\end{array}$ & 2.9 & 0.50 \\
$\begin{array}{l}\text { yang semakin meningkat } \\
\text { Tingkat kebutuhan yang semakin }\end{array}$ & 0.155 & 3 & 0.47 \\
$\begin{array}{l}\text { tinggi } \\
\text { Kemajuan dalam teknik perawatan } \\
\text { kulit dan produk kecantikan }\end{array}$ & 0.168 & 2.4 & 0.40 \\
$\begin{array}{l}\text { 6. Banyaknya penduduk yang bekerja, } \\
\text { kuliah, maupun yang masih sekolah }\end{array}$ & 0.172 & 3.6 & 0.62 \\
TOTAL & 1 & & 2.98
\end{tabular}

Sumber: Data Diolah, 2020

\section{Analisis Diagram SWOT}

Di dalam analisis Diagram SWOT ini menggunakan data hasil pengolahan kuesioner seperti yang tercantum pada Tabel 1- Tabel 4. Dengan keempat tabel tersebut akan didapat skor yang menunjukkan identifikasi faktor-faktor yang digunakan untuk merumuskan strategi perusahaan.

Dari gambar 1, hasil pengolahan kuesioner, posisi Dasom \& Me Nail pada diagram SWOT, digambarkan oleh titik yang berbentuk dari perpotongan garis diagonal koordinat titik, yaitu :

Titik A $(3,37: 2,98)$

Titik B $(3,37:-2,60)$

Titik C $(-2,61:-2,60)$

Titik D $(-2,61: 2,98)$ 


\section{Tabel 4}

Kuesioner Internal Faktor Analisis Strategi untuk Mengetahui Ancaman (Threats)

\begin{tabular}{|c|c|c|c|}
\hline Faktor Strategi & Bobot & Rating & SKOR (Bobot x Rating) \\
\hline 1. Banyaknya perusahaan yang sejenis & 0.141 & -2.5 & -0.35 \\
\hline $\begin{array}{l}\text { 2. Kenaikkan harga produk disebabkan } \\
\text { harga bahan baku yang naik turun }\end{array}$ & 0.141 & -2.4 & -0.34 \\
\hline 3. Perubahan selera konsumen & 0.154 & -2.8 & -0.43 \\
\hline 4. Tuntutan upah, bonus/insentif (naik) & 0.145 & -2.6 & -0.38 \\
\hline $\begin{array}{l}\text { 5. Ada pihak lain (salon kecantikan) } \\
\text { memberikan harga murah atau diskon }\end{array}$ & 0.141 & -2.5 & -0.35 \\
\hline $\begin{array}{l}\text { 6. Banyaknya isu penggunaan Produk } \\
\text { berbahaya }\end{array}$ & 0.141 & -2.6 & -0.37 \\
\hline $\begin{array}{l}\text { 7. Banyaknya stok barang yang tidak } \\
\text { terjual secara keseluruhan }\end{array}$ & 0.137 & -2.8 & -0.38 \\
\hline TOTAL & 1 & & -2.60 \\
\hline
\end{tabular}

Sumber: Data Diolah, 2020

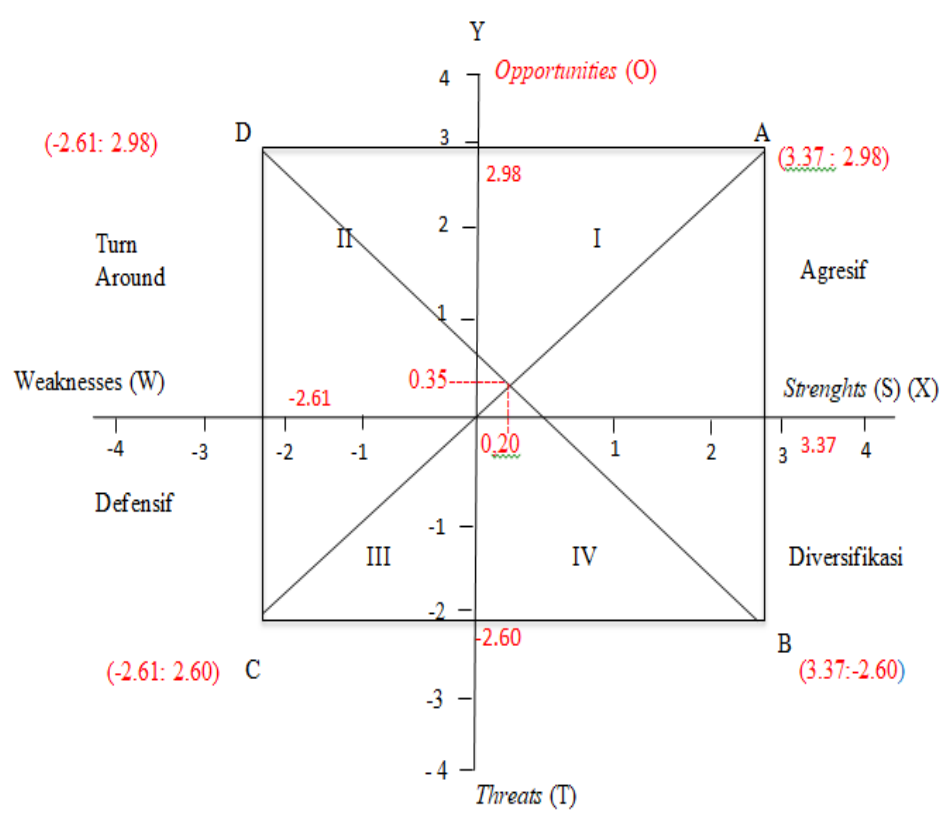

Sumber: Data Diolah, 2020

\section{Gambar 1}

\section{Diagram SWOT}

Tabel 5

Faktor Internal

\begin{tabular}{ccc}
\hline No & Faktor Strategi & Skor \\
\hline 1 & Faktor kekuatan (Strengths) & 3.37 \\
2 & Faktor kelemahan (Weaknesses) & -2.61 \\
Total & & 0.76 \\
\hline
\end{tabular}

Sumber: Data Diolah, 2020 
Tabel 6

Faktor Eksternal

\begin{tabular}{llc}
\hline No & Faktor Strategi & Skor \\
\hline 1 & Faktor Peluang (Opportunities) & 2.98 \\
2 & Faktor Ancaman (Threats) & -2.60 \\
Total & & 0.38 \\
\hline
\end{tabular}

Sumber: Data Diolah, 2020

\section{Data Evaluasi Faktor Internal}

Data ini merupakan hasil dari pengolahan kuesioner faktor internal (strengths dan weaknesses), maka dapat ditampilkan dalam tabel 5.

\section{Data Evaluasi Faktor Eksternal}

Data ini merupakan hasil dari pengolahan kuesioner faktor eksternal (Opportunities dan

Threats), maka dapat ditampilkan dalam tabel 6 .

\section{Analisis Matrik SWOT}

Rangking yang didapat oleh masing-masing kuadran harus dikonversikan ke dalam rumusan Matrik SWOT. Dalam rumusan Matrik SWOT terdapat 4 strategi utama yaitu :

a. Strategi SO (Strengths dan Opportunities) pada kuadran I

b. Strategi WO (Weaknesses dan Opportunities) pada kuadran II

c. Strategi WT (Weaknesses dan Threats) pada kuadran III

d. Strategi ST (Strengths dan Threats) pada kuadran IV

Hasil penentuan rangking dan perhitungan diatas, menunjukkan bahwa rangking ke-1 terdapat pada kuadran I, rangking ke-2 terdapat pada kuadran IV, rangking ke-3 terdapat pada kuadran III dan rangking ke-4 terdapat pada kuadran II. Dengan demikian bila dikonversi ke dalam matrik SWOT akan diketahui strategi yang paling tepat untuk diterapkan pada Dasom Beauty \& Me Nail Surabaya yaitu strategi SO (Strengths dan Opportunities). Dimana Dasom Beauty \& Me Nail Surabaya harus memanfaatkan kekuatannya secara optimal untuk merebut peluang yang ada, dengan memperhatikan setiap ancaman.

\section{Hasil Matrik Internal-Eksternal}

Internal-Eksternal ini merupakan skor total dari penjumlahan untuk:

a. Faktor Internal (Strengths + Weaknesses) $=3.37+(-2.61)=0.76$

b. Faktor Eksternal (Opportunities + Threats) $=2.98+(-2.60)=0.38$

Nilai ini merupakan skor dengan range skala antara -4 sampai dengan 4 , sehingga untuk penyesuaian dengan Matrik Internal-Eksternal, dilakukan interpolasi nilai range skala -4 hingga 4 menjadi range skala 0 hingga 4.Sehingga didapat hasil :

a. Faktor Internal $=0,76$ (vertikal)

b. Faktor Eksternal = 0,38 (horizontal)

Sehingga pada titik perpotongan garis tersebut matrik Internal-Eksternal yaitu pada posisi GROWTH and STABILITY. 


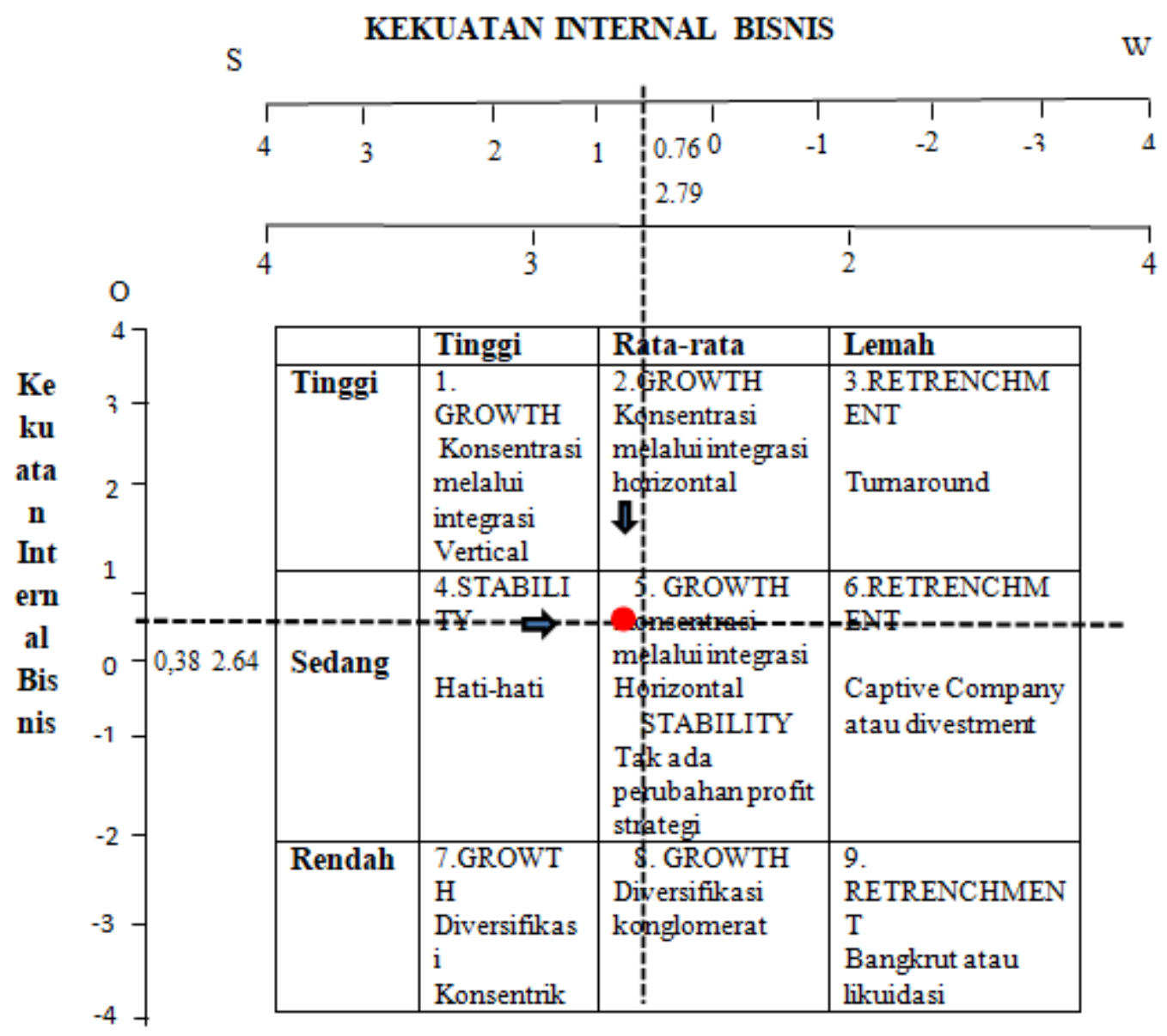

Sumber: Data Diolah, 2020

Gambar 2

Matrik Internal - Eksternal

\section{SIMPULAN DAN SARAN}

Berdasarkan penelitian yang telah dilakukan, maka dapat ditarik beberapa kesimpulan sebagai berikut: Hasil analisis SWOT pada lingkungan internal perusahaan menjelaskan bahwa Dasom Beauty \& Me Nail Surabaya memiliki kekuatan dan kelemahan terkait dengan kegiatan pengembangan usahanya. Dari pengolahan kuesioner, diperoleh hasil posisi perusahaan pada titik $\mathrm{x}$ berada pada kuadran I, dimana perusahaan memiliki cukup kekuatan untuk memanfaatkan peluang yang tersedia. Dengan memperhatikan kedekatan titik $\mathrm{x}$ terhadap kuadran IV, dimana ancaman cukup menekan perusahaan dalam persaingan.

\section{DAFTAR PUSTAKA}

Kotler Philip, Kevin Lane Keller. 2016. Managemen Pemasaran, Edisi keduapuluh tiga. Jakarta: Gelora Aksara Pratama. 
Rangkuti, Freddy. 2019. Analisis SWOT : Teknik membedah Kasus Bisnis (cara perbitungan Bobot, Rating, dan OCAI. Cetakan keduapulih Lima. Jakarta: PT Gramedia Pustaka Umum.

Suparyanto dan Rosad. 2015. Manajemen Pemasaran. Bogor: IN MEDIA. 